\title{
Altered Platelet Peripheral-Type Benzodiazepine Receptor in Posttraumatic Stress Disorder
}

\author{
Moshe Gavish, Ph.D., Nathaniel Laor, M.D., Ph.D., Miri Bidder, D.Sc., Daniel Fisher, M.D., \\ Ora Fonia, B.Sc., Uri Muller, M.D., Ahuva Reiss, M.D., Leo Wolmer, M.A., \\ Leon Karp, M.D., and Ronit Weizman, M.D.
}

Peripheral-type benzodiazephine receptors (PBR) are involved in steroidogenesis and are sensitive to stress. Reduced platelet $P B R$ density has been demonstrated in generalized anxiety disorder (GAD), but not in obsessivecompulsive disorder (OCD). We extended this observation to another anxiety disorder, namely, posttraumatic stress disorder (PTSD). Eighteen post-Persian Gulf War PTSD patients and 17 age-and sex-matched controls were included in the study. All subjects were evaluated using the Structured Clinical Interview for DSM-III-R-Patient Version. The severity of symptoms was assessed using the DSM-III-R scale for PTSD, the Impact of Event Scale, the
Beck Depression Inventory, and the State-Trait Anxiety Inventory. $\left[{ }^{3} \mathrm{H}\right] \mathrm{PK} 11195$ was used to label platelet PBR. All psychological parameters (except trait anxiety) were higher in PTSD patients compared to controls. Decreased platelet PBR density $(-62 \% ; p<.001)$ was observed in the $P T S D$ patients compared to controls. The reduction in $P B R$ observed in PTSD patients was in accordance with the findings in $G A D$ patients, but differed from those obtained in OCD patients. It is possible that the receptoral downregulation is an adaptive response aimed at preventing chronic overproduction of glucocorticoids in hyperarousal states. [Neuropsychopharmacology 14:181-186, 1996]
KEY WORDS: Posttraumatic stress disorder; Peripheral-type benzodiazepine receptor; Anxiety

Peripheral-type benzodiazepine receptors (PBR) are prominent in peripheral organs, whereas in the brain they are sparse (Wang et al. 1980; Schoemaker et al. 1981; Taniguchi et al. 1982; Anholt et al. 1985; Basile et al. 1986; Gavish et al. 1992, 1993). PBR differ from central-type benzodiazepine receptors in their distribution within

From the Department of Pharmacology (MG, MB, DF), The Bruce Rappaport Faculty of Medicine and the Rappaport Family Institute for Research in the Medical Sciences, Technion-Israel Institute of Technology, Haifa, Israel; Tel Aviv Community Mental Health Center (RW, NL, DF, UM, AR, LW), Ramat Hatayassim, Israel; Geha Psychiatric Hospital (LK), Petah Tiqva, Israel; Sackler Faculty of Medicine (RW, NL, UM, LK), Tel Aviv University, Tel Aviv, Israel; and Yale Child Study Center (NL), New Haven, Connecticut.

Address correspondence to: Ronit Weizman, M.D., Psychopharmacology Unit, Tel Aviv Community Mental Health Center, 9 Hatzvi Street, Ramat Hatayassim, 67197 Tel Aviv, Israel.

Received December 29, 1994; revised April 21, 1995; accepted May 1, 1995. the brain, their lack of coupling to the $\gamma$-aminobutyric acid receptors, and their specificity to ligand binding. Recently, the amino acids sequence of human PBR has been deduced from corresponding CDNA (Sprengel et al. 1989; Krueger et al. 1990), and the PBR gene has been located in the 13.3 region of the long arm of human chromosome 22 (Riond et al. 1991). The involvement of PBR in acute and chronic stress has been examined in several animal models and in some human studies (Rägo et al. 1989; Holmes et al. 1992; Dodd and Lenfant 1993; Gavish et al. 1993; Weizman and Gavish 1994). The modulatory effect of stress on the expression of PBR is in an organ-specific fashion and bidirectional, i.e., upregulation after acute stress and downregulation after long-term exposure to stress (Gavish et al. 1992, 1993).

In a previous study we demonstrated lower PBR density in patients with generalized anxiety disorder (GAD) compared to control subjects, and normalization of platelet PBR values after diazepam treatment (Weiz- 
man et al. 1987). On the other hand, in a subsequent study, we could not find a similar decrease in platelet PBR density in a group of patients with obsessive-compulsive disorder (OCD) (Weizman et al. 1993), which is also characterized by long-term stress. Thus, it seems that PBR may not be uniformly altered in all anxiety disorders, but rather may be restricted to those anxiety disorders associated with persistent activation of the autonomic nervous system. In order to test our hypothesis, we designed the current study, in which platelet PBR were measured in drug-free posttraumatic stress disorder (PTSD), a chronic disorder that involves high anxiety levels and hyperarousal of the autonomic nervous system.

\section{PATIENTS AND METHODS}

\section{Subjects}

Eighteen PTSD outpatients (five men and 13 women) aged 25 to 69 years (mean \pm SD, $47.1 \pm 15.4$ years) and 17 control subjects ( 10 men and seven women) aged 29 to 65 years (mean $\pm \mathrm{SD}, 47.5 \pm 11.4$ years) participated in the study. All subjects were fully informed about the nature of the study and gave their written consent. Patients and controls were recruited from the Tel Aviv area, and all had been exposed to repeated missile attacks during the Persian Gulf War. All patients reported that their symptoms had appeared after the Gulf War and had persisted for 2 years, when the study was conducted. All participants were physically healthy, drug-free, and with no history of intake of psychotropic medication or alcohol or of drug abuse or addiction. The PTSD patients had applied to the PTSD clinic, established in the hit neighborhood after the war, and received cognitive and group psychotherapy.

All subjects (patients and controls) were evaluated by a senior psychiatrist using the Structural Clinical Interview for DSM-III-R-Patient Version (SCID-P) (Spitzer et al. 1989). PTSD was evaluated using the Harvard Upjohn Anxiety/Panic Disorder Research Project (HARP) supplemented for PTSD for the SCID-P. All patients met the DSM-III-R criteria for PTSD, and 11 out of the 18 patents also met the criteria for current major affective disorder. All control subjects included in the study had no lifetime Axis I disorder, as assessed by SCID-P. The severity of the symptoms was assessed using: (1) the DSM-III-R scale for PTSD (Solomon et al. 1993), (2) the Impact of Event Scale (Horowitz et al. 1979), (3) the Beck Depression Inventory (Beck et al. 1961), and (4) the State-Trait Anxiety Inventory (Spielberger et al. 1977).

\section{Materials}

$\left[{ }^{3} \mathrm{H}\right] \mathrm{PK} 11195$ (92.3 Ci/mmol) was purchased from New England Nuclear, Boston, MA. Unlabeled PK 11195 was a generous gift from Dr. Anne Bouvier, Rhône-Poulenc Santé, Vitry sur Seine, France. Lumax was purchased from Lumac, Schaesberg, the Netherlands. All other chemicals were purchased from commercial sources.

\section{Membrane Preparation}

Blood samples $(27 \mathrm{ml})$ for assessment of $\left[{ }^{3} \mathrm{H}\right] \mathrm{PK} 11195$ binding were drawn from the subjects between 9:00 A.M. and 10:00 A.M., collected into plastic tubes containing $3 \mathrm{ml}$ of $3.8 \%$ sodium citrate, and spun at $180 \times g$ for 15 minutes at $23^{\circ} \mathrm{C}$. Platelet-rich plasma was collected and spun at $1,500 \times g$ for 15 minutes at $23^{\circ} \mathrm{C}$. The platelet-containing pellet was frozen at $-70^{\circ} \mathrm{C}$ until assay. Prior to binding assay, the samples were thawed, and each pellet was homogenized in $20 \mathrm{ml}$ of $50 \mathrm{mmol} / \mathrm{L}$ Tris- $\mathrm{HCl}$ buffer, $\mathrm{pH} 7.4$, at $4^{\circ} \mathrm{C}$ with a Brinkmann polytron (setting 10) for 15 seconds and centrifuged at $49,000 \times$ $g$ for 15 minutes at $4^{\circ} \mathrm{C}$. The procedure was immediately repeated. The pellet was homogenized in $15 \mathrm{ml}$ of Tris$\mathrm{HCl}$ buffer and used for binding studies.

\section{[ $\left.{ }^{3} \mathrm{H}\right]$ PK 11195 Binding Assay}

[ $\left.{ }^{3} \mathrm{H}\right] \mathrm{PK} 11195$ binding was conducted as previously described (Weizman et al. 1993). Binding assay in a final volume of $500 \mu$ l contained $400 \mu \mathrm{l}$ platelet membranes (70 to $100 \mu \mathrm{g}$ protein) and $25 \mu \mathrm{l}\left[{ }^{3} \mathrm{H}\right] \mathrm{PK} 11195$ (final concentration 0.2 to $8 \mathrm{~mol} / \mathrm{L}$ ) in the absence (total binding) or presence (nonspecific binding) of $10 \mu \mathrm{mol} / \mathrm{L}$ unlabeled PK 11195. After incubation for 60 minutes at $4^{\circ} \mathrm{C}$, samples were filtered under vacuum over Whatman GF/B filters and washed three times with $3 \mathrm{ml}$ of Tris$\mathrm{HCl}$ buffer. Filters were placed in vials containing $5 \mathrm{ml}$ of xylene-Lumax (3:1, vol/vol) and counted for radioactivity. Equilibrium dissociation constant $\left(\mathrm{K}_{\mathrm{d}}\right)$ and maximal number of binding sites $\left(B_{\max }\right)$ were determined by Scatchard analysis of saturation curves of $\left[{ }^{3} \mathrm{H}\right] \mathrm{PK} 11195$ binding. The binding parameters were analyzed for each subject individually.

\section{Statistical Analysis}

Psychological and biochemical variables were separately analyzed using multivariate analysis of variance (MANOVA), with group (PTSD versus controls) and sex (males versus females) as between-subject factors. Differences between PTSD subjects with and without DSM-III-R diagnosis of major depression were similarly assessed using the MANOVA procedure. Finally, differences between men and women on individual measures were examined with two-tailed unpaired Student's $t$-test. Pearson's product-moment correlations were used to examine relationships among selected measures. 


\section{RESULTS}

The psychological and biochemical data of the study population and univariate analyses are summarized in Table 1 and Figure 1.

MANOVA analysis for the psychological measures yielded significant effects for group on the multivariate $(F=168.7, d f=6,26, p<.001)$ as well as on the univariate tests. As expected, the PTSD group scored higher than the controls on every psychological variable $(p<.001)$ except on the anxiety trait domain $(p>.05)$. No sex differences were found on multivariate analysis $(F=1.18$, $d f=6,26, p>.05)$. However, men scored higher than women on the PTSD inventory $(F=4.83, d f=1,31, p<$ $.05)$. The group $\times$ sex interaction did not reach statistical significance $(F=0.79, d f=6,26, p>.05)$.

With the biochemical variables a significant multivariate effect was found for group $(F=20.21, d f=2,30$, $p<.001)$. The multivariate $\operatorname{sex}(F=0.10, d f=2,30, p>$ $.05)$ and group $\times$ sex effects $(F=3.01, d f=2,30, \mathrm{p}>.05)$ did not reach statistical significance. For $B_{\max }$ univariate analysis showed a significant group effect, with control subjects showing higher levels than PTSD subjects ( $F=$ $41.2, d f=1,31, p<.001)$. Also, a significant group $\times$ sex interaction $(F=5.28, d f=1,31, d f=1,31, p<.05)$ was found for $B_{\text {max }}$. In order to further examine this interaction, posthoc tests were conducted and revealed that among PTSD subjects, $B_{\max }$ level was significantly lower in men as compared to women $(t=2.25, d f=16, p<$ $.05)$. Within the control group no significant sex differences appeared $(t=1.59, d f=15, p>.05)$. For $K_{d}$ no univariate effects were found. $B_{\max }$ and $K_{d}$ values did not differ between PTSD patients with and without major depression $(F=1.71, d f=2,15, p>.05)$.

Further psychological and biochemical measures were

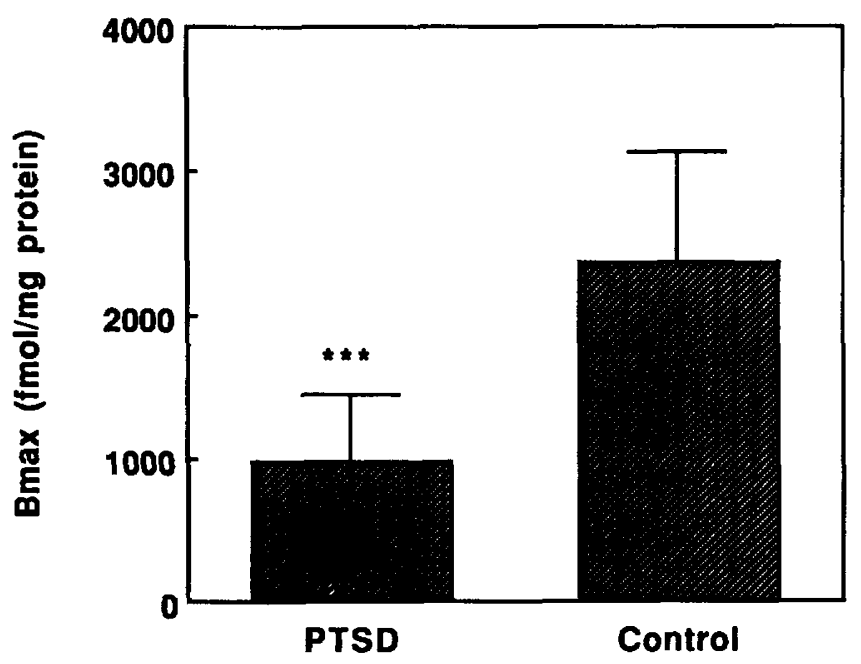

Figure 1. Maximal binding capacity $\left(\mathrm{B}_{\max }\right)$ of $\left[{ }^{3} \mathrm{H}\right] \mathrm{PK} 11195$ in PTSD patients and control subjects (mean \pm SD). ${ }^{* *} p<$ .001 versus controls.

compared by MANOVA analyses in PTSD subjects with and without comorbidity of major depression or anxiety disorder. Results showed that no significant differences were found on the psychological measures (all $p>.05$ ). However, $B_{\max }$ levels of PTSD subjects with panic disorder (PD) were significantly lower compared to those of PTSD patients without PD (means $\pm \mathrm{SD}=637.8 \pm 325.6$ and $1155.2 \pm 435.6$, respectively) $(F=6.54, d f=1,16, p<$ .05). The comparison of $B_{\max }$ levels in PTSD patients with and without agoraphobia rendered similar results: posttraumatic subjects with agoraphobia showed significantly lower $B_{\max }$ levels compared to those without agoraphobia (means $\pm \mathrm{SD}=402.5 \pm 170.8$ and $1178.5 \pm$ 379.2 , respectively) $(F=14.2, d f=1,16, p<.005)$.

Table 1. Psychological and Biochemical Variables of the Study Population (mean \pm SD)

\begin{tabular}{|c|c|c|c|c|c|c|c|}
\hline \multirow[b]{2}{*}{ Variable } & \multicolumn{3}{|c|}{ PTSD Group } & \multicolumn{3}{|c|}{ Non-PTSD Group } & \multirow{2}{*}{$\begin{array}{c}\text { Group Effect } \\
\text { (PTSD versus } \\
\text { Controls) }\end{array}$} \\
\hline & $\begin{array}{c}\text { Men } \\
(n=5)\end{array}$ & $\begin{array}{l}\text { Women } \\
(n=13)\end{array}$ & $\begin{array}{c}\text { Men + women } \\
(n=18)\end{array}$ & $\begin{array}{c}\text { Men } \\
(n=10)\end{array}$ & $\begin{array}{l}\text { Women } \\
(n=7)\end{array}$ & $\begin{array}{c}\text { Men + women } \\
(n=17)\end{array}$ & \\
\hline Psychological & & & & & & & $d f=1,31$ \\
\hline PTSD inventory & $61.8 \pm 1.8$ & $56.5 \pm 5.8$ & $57.9 \pm 5.6$ & $19.4 \pm 1.5$ & $18.8 \pm 11.5$ & $18.8 \pm 3.0$ & $695.8^{a}$ \\
\hline Intrusion (IES) & $28.0 \pm 0.0$ & $25.3 \pm 3.5$ & $26.1 \pm 3.2$ & $8.1 \pm 2.0$ & $7.6 \pm 0.8$ & $7.9 \pm 1.6$ & $450.8^{a}$ \\
\hline Avoidance (IES) & $20.2 \pm 3.4$ & $20.0 \pm 3.2$ & $20.2 \pm 3.2$ & $10.3 \pm 3.1$ & $15.1 \pm 6.0$ & $8.8 \pm 2.5$ & $94.7^{a}$ \\
\hline Total IES ${ }^{b}$ & $48.2 \pm 3.4$ & $45.5 \pm 4.5$ & $46.3 \pm 4.3$ & $17.5 \pm 3.8$ & $17.8 \pm 3.4$ & $17.8 \pm 3.4$ & \\
\hline Anxiety state & $73.2 \pm 3.3$ & $71.7 \pm 4.7$ & $72.1 \pm 4.7$ & $27.6 \pm 6.2$ & $26.8 \pm 5.0$ & $27.3 \pm 5.6$ & $695.8^{a}$ \\
\hline Anxiety trait & $45.6 \pm 4.2$ & $47.5 \pm 1.5$ & $47.0 \pm 2.5$ & $48.6 \pm 1.7$ & $47.7 \pm 2.6$ & $48.2 \pm 2.1$ & 3.7 \\
\hline BDI & $26.0 \pm 8.1$ & $24.2 \pm 9.1$ & $24.7 \pm 8.7$ & $0.8 \pm 1.6$ & $0.1 \pm 0.4$ & $0.5 \pm 1.3$ & 112.4 \\
\hline Biochemical & & & & & & & $d f=2,30$ \\
\hline $\mathrm{B}_{\max }(\mathrm{fmol} / \mathrm{mg}$ protein $)$ & $664 \pm 333$ & $1105 \pm 460$ & $982 \pm 466$ & $2592 \pm 812$ & $2017 \pm 677$ & $2356 \pm 783$ & $41.2^{a}$ \\
\hline$K_{d}(n M)$ & $4.3 \pm 2.4$ & $3.9 \pm 1.9$ & $4.0 \pm 2.0$ & $5.8 \pm 2.4$ & $5.4 \pm 2.3$ & $5.6 \pm 2.3$ & 3.5 \\
\hline
\end{tabular}

Abbreviations: IES $=$ Impact of Event Scale; BDI $=$ Beck Depression Inventory.

${ }^{a} p<.001$.

${ }^{b}$ The total IES score was not included in the MANOVA. 
No significant correlations were found between biochemical measures and psychological variables within PTSD patients or within control subjects $(p>.05)$.

\section{DISCUSSION}

The present study revealed a significant robust decrease $(-62 \%$ of control; $p<.001)$ in platelet PBR density in post-Gulf War PTSD patients compared to controls. As expected, the psychological measures (except anxiety trait) in the patients were significantly higher than in the controls.

Acute stress has been demonstrated to upregulate PBR, whereas chronic stress decreases receptor density (Gavish et al. 1992; Weizman and Gavish 1994). The impact of acute and chronic stress on PBR has been investigated extensively in various animal models as well as in humans (for review, see Gavish et al. 1992; Weizman and Gavish 1994). Acute stress has been demonstrated to upregulate PBR, whereas chronic stress decreases receptor density. Five inescapable tail shocks in rats induced a significant increase of renal PBR, whereas 80 repeated tail shocks resulted in a significant decrease of PBR density in cerebral cortex, pituitary gland, heart, and kidney (Drugan et al. 1986). A similar increase in PBR after acute stress has also been demonstrated in rodents exposed to acute maximal electroshock (Basile et al. 1987), a single experience of forced swimming stress (Rägo et al. 1989), and surgical stress (Okun et al. 1988).

In humans, upregulation of platelet PBR was detected in resident physicians exposed to examination stress (Karp et al. 1989). Maudsley reactive rats, which have been bred for a high level of fearfulness, show decreased PBR density in kidney and heart (Drugan et al. 1987). Similar decrease in PBR density has been observed in rodents exposed to repeated maximal electroshock administration (Basile et al. 1987) and food deprivation (Weizman et al. 1990). In humans, depletion of platelet PBR density was observed in soldiers exposed to repeated parachute jumps (Dar et al. 1991) and in anxious patients (Weizman et al. 1987).

The exact mechanisms that play a role in the modulation of the receptor expression in response to stress are as yet not well established. In steroidogenic tissues, PBR ligands can affect the translocation of cholesterol from the outer to the inner mitochondrial membrane, but the absolute rate changes are limited (Krueger and Papadopoulos 1990). As stress is accompanied by an increase in glucocorticoid synthesis and release, it is possible that this receptor plays a pivotal role in the neuroendocrine response to stress. It seems that, in order to avoid long-term hypercortisolemia secondary to stress, which may provoke damage to central and peripheral systems, the maximal binding capacity of the receptor is diminished.

It should be noted that in the present study we measured plasma membrane PBR in platelets, assuming that the changes would reflect those in mitochondrial PBR located in steroidogenic tissues. Furthermore, it is noteworthy, regarding PBR, that only a small fraction of intracellular cholesterol is available for steroid synthesis, and the uptake of cholesterol from plasma is stimulated by adrenocorticotrophic hormone (Krueger and Papadopoulos 1990). Unfortunately, we did not measure steroid levels and thus were unable to demonstrate whether reduced PBR density was associated with lowered steroid levels. However, it has previously been reported that chronic stress (in contrast to acute stress) leads to diminished cortisol secretion (for review, see Mason et al. 1990; Yehuda et al. 1990).

As a consequence of decreased PBR expression, cholesterol transport into the mitochondria is reduced, and steroid biosynthesis slows down. The observation that in PTSD patients PBR density was lower in men than women is consistent with the finding of sexual dimorphism in renal PBR response to stress in rats; i.e., female rats showed an attenuated stress-induced reduction in PBR in comparison to male rats (Drugan et al. 1991, 1993). However, the human sexual dimorphism of stressinduced changes in PBR needs a further evaluation in a larger population of PTSD patients.

It is noteworthy that the downregulation of the receptor is not observed in all the psychiatric conditions defined by DSM-III-R as anxiety disorders. A reduction in platelet PBR was previously detected in GAD (Weizman et al. 1987) and PD (Marazziti et al. 1994), as also demonstrated in the present study in PTSD, but not in OCD (Weizman et al. 1993; Marazziti et al. 1994). On the pharmacologic level, amelioration of anxiety is achieved by benzodiazepines in GAD, PD, and PTSD, but not in OCD patients (who benefit only from serotonin reuptake inhibitors) (Weizman et al. 1993). Taking into consideration the different sensitivities of the receptor in these anxiety disorders and the different responses to drug treatment, it seems possible that the disorders differ from one another. The common neurophysiologic basis in GAD, PD, and PTSD seems to be long-term repeated hyperactivity of the autonomic nervous system. The receptoral downregulation may reflect an adaptive response aimed at preventing chronic overproduction of glucocorticoids in hyperarousal states.

\section{ACKNOWLEDGMENTS}

Dr. Gavish and Dr. Weizman were supported by Grant 181499 from the Fund for the Promotion of Research at the Technion. We thank Ruth Singer for typing and editing the manuscript. 


\section{REFERENCES}

Anholt RRH, De Souza EB, Oster-Granite ML, Snyder SH (1985): Peripheral-type benzodiazepine receptors: Autoradiographic localization in whole-body sections of neonatal rats. J Pharmacol Exp Ther 233:517-526

Basile AS, Klein DC, Skolnick P (1986): Characterization of benzodiazepine receptors in the bovine pineal gland: evidence for the presence of an atypical binding site. Mol Brain Res 1:127-135

Basile AS, Weissman BA, Skolnick P (1987): Maximal electroshock increases the density of $\left[{ }^{3} \mathrm{H}\right]$ Ro 5-4864 binding to mouse cerebral cortex. Brain Res Bull 19:1-7

Beck AT, Ward CH, Mendelson M, Mock J, Ernbaugh J (1961): An inventory for measuring depression. Arch Gen Psychiatry 4:561-571

Dar DE, Weizman A, Karp L, Grinshpoon A, Bidder M, Kotler M, Tyano S, Bleich A, Gavish M (1991): Platelet peripheral benzodiazepine receptors in repeated stress. Life Sci 48:341-346

Dodd RH, Lenfant M (1993): Modification of mitochondrial benzodiazepine receptor number in stressful situations. In Giessen-Crouse E (ed), Peripheral Benzodiazepine Receptors. London, Academic Press, pp 187-207

Drugan RC, Basile AS, Crawley JN, Paul SM, Skolnick P (1986): Inescapable shock reduced [ $\left.{ }^{3} \mathrm{H}\right]$ Ro $5-4864$ binding to "peripheral type" benzodiazepine receptors in the rat. Pharmacol Biochem Behav 24:1,673-1,677

Drugan RC, Basile AS, Crawley JN, Paul SM, Skolnick P (1987): "Peripheral" benzodiazepine binding sites in Maudsley reactive rats: Selective decrease confined to peripheral tissues. Brain Res Bull 18:143-145

Drugan RC, Holmes PV, Stringer AP (1991): Sexual dimorphism of stress-induced changes in renal peripheral benzodiazepine in rat. Neuropharmacology 30:413-416

Drugan RC, Park R, Kaufman L, Holmes PV (1993): Etiology of the sexual dimorphism in renal peripheral benzodiazepine receptor response to stress in rats. Horm Behav 27:348-365

Gavish M, Katz Y, Bar-Ami S, Weizman R (1992): Biochemical, physiologic, and pathologic aspects of the peripheral benzodiazepine receptor. J Neurochem 58:1,589-1,601

Gavish M, Bar-Ami S, Weizman R (1993): Pathophysiologic and endocrinologic aspects of peripheral-type benzodiazepine receptors. In Giesen-Crouse E (ed), Peripheral Benzodiazepine Receptors. London, Academic Press, pp 209-234

Holmes PV, Stringer AP, Drugan RC (1992): Impact of psychological dynamics of stress on the peripheral benzodiazepine receptor. Pharmacol Biochem Behav 2:437-444

Horowitz M], Wilner N, Alvarez W (1979): Impact of Event Scale: A measure of subjective distress. Psychosom Med 41:207-218

Karp L, Weizman A, Tyano S, Gavish M (1989): Examination stress, platelet peripheral benzodiazepine binding sites, and plasma hormone levels. Life Sci 44:1,077-1,082

Krueger KE, Papadopoulos V (1990): Peripheraltype benzodiazepine receptors mediate translocation of cholesterol from outer to inner mitochondrial membranes in adrenocortical cells. J Biol Chem 265:15,015-15,022
Krueger KE, Mukhin AG, Antkiewicz-Michaluk L, Santi MR, Grayson DR, Guidotti A, Sprengel R, Werner P, Seeburg PH (1990): Purification, cloning, and expression of a peripheral-type benzodiazepine receptor. Adv Biochem Psychopharmacol 46:1-13

Marazziti D, Rotondo A, Martini C, Giannacini G, Lucacchini A, Diamond BI, Borison R, Cassano GB (1994): Changes in peripheral benzodiazepine receptors in patients with panic disorder and obsessive-compulsive disorder. Neuropsychobiology 29:8-11

Mason JW, Giller EL, Kosten TR, Yehuda R (1990): Psychoendocrine approaches to the diagnosis and pathogenesis of posttraumatic stress disorder. In Giller EL (ed), Biological Assessment and Treatment of Posttraumatic Stress Disorder. Washington, DC, American Psychiatric Press, pp 65-86

Okun F, Weizman R, Katz Y, Bomzon A, Youdim MBH, Gavish $M$ (1988): Increase in central and peripheral benzodiazepine receptors following surgery. Brain Res 458:31-36

Rägo L, Kivet R-A, Harro J, Pold M (1989): Central and peripheraltype benzodiazepine receptors: Similar regulation by stress and GABA receptor agonists. Pharmacol Biochem Behav 32:879-883

Riond J, Mattei MG, Kaghand M, Dumont X, Guillemot JC, Le Fur G, Caput D, Ferrara P (1991): Molecular cloning and chromosomal localization of a human peripheral-type benzodiazepine receptor. Eur J Biochem 195:305-311

Schoemaker H, Bliss M, Yamamura HI (1981): Specific highaffinity saturable binding of $\left[{ }^{3} \mathrm{H}\right]$ Ro $5-4864$ to benzodiazepine binding sites in the rat cerebral cortex. Eur J Pharmacol 71:173-175

Solomon Z, Benbemishty R, Neria Y, Abramowitz M, Ginzburg K, Ohry A (1993): Assessment of PTSD: Validation of the revised PTSD inventory. Isr J Psychiatry 30:110-115

Spielberger CD, Borsuch RL, Lushene RE (1977): Manual of the State-Trait Anxiety Inventory. Palo Alto, CA, Consulting Psychologist Press

Spitzer RL, Williams JBW, Gibbon M, First MB (1989): Structured Clinical Interview for DSM-III-R-Patient Version (SCID-P). New York, New York State Psychiatric Institute

Sprengel R, Werner P, Seeburg PH, Mukhin AG, Santi MR, Grayson DR, Guidotti A, Krueger KE (1989): Molecular cloning and expression of a cDNA encoding a peripheraltype benzodiazepine receptor. J Biol Chem 264: 20,41520,421

Taniguchi T, Wang JKT, Spector S (1982): [ ${ }^{3}$ H]Diazepam binding sites on rat heart and kidney. Biochem Pharmacol 31:589-590

Wang JKT, Taniguchi T, Spector S (1980): Properties of [ $\left.{ }^{3} \mathrm{H}\right]-$ diazepam binding on rat blood platelets. Life Sci 27:1,8811,888

Weizman R, Tanne Z, Granek M, Karp L, Golomb M, Tyano $S$, Gavish M (1987): Peripheral benzodiazepine binding sites on platelet membranes are increased during diazepam treatment of anxious patients. Eur J Pharmacol 138:289-292.

Weizman A, Bidder M, Fares F, Gavish M (1990): Food deprivation modulates $\gamma$-aminobutyric acid receptors and peripheral benzodiazepine binding sites in rats. Brain Res 535:96-100 
Weizman R, Hermesh H, Karp L, Dar DE, Munitz H, Gavish M (1993): The platelet benzodiazepine receptor is unaltered in obsessive-compulsive disorder. Clin Neuropharmacol 16:211-215

Weizman R, Gavish M (1994): Molecular cellular and behavioral aspects of peripheral-type benzodiazepine receptors. Clin Neuropharmacol 16:401-417
Yehuda R, Southwick SM, Perry BD, Mason JW, Giller EL (1990): Interactions of the hypothalamic-pituitary-adrenal axis and the catecholaminergic system in posttraumatic stress disorder. In Giller EL (ed), Biological Assessment and Treatment of Posttraumatic Stress disorder. Washington, DC, American Psychiatric Press, pp 115-134 